\title{
Nasjonalrapport for Norge
}

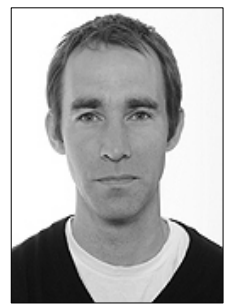

Martin Børresen

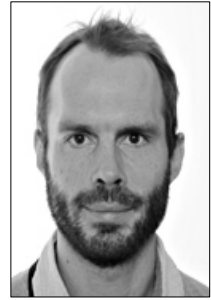

Marius Pilgaard

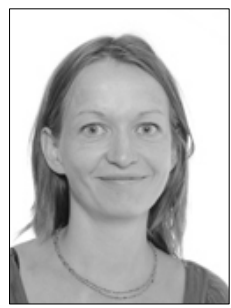

Marie Bjørneby

Abstract: Since the Tax Reform of 1992 Norway has had a tax system of relatively low tax rates and broad tax bases. Norway, along with other Nordic neighbours, did quite early substantially reduce its statutory corporate tax rate - reduced from 50.8 to 28 per cent as part of the 1992 Reform. After 1992 the rate has been constant at 28 until it was reduced marginally to 27 in 2014 . Since 1992 the principal objective in designing the corporate tax system has been to ensure resource effectiveness. The role of the corporate (and capital) income tax is therefore to secure public revenue but at the same time minimising distortion. An important feature of the system is therefore that normal return on capital is taxed at the same rate, irrespective of whether it is earned as business income or not.

The Report identifies three main challenges to the current corporate tax system. The first challenge discussed is the system's effects on investments. It cannot be overlooked that the corporate tax rate in Norway is currently higher than the tax rate of many countries Norway is commonly compared with (e.g. other Nordic countries). The Report suggests that this can contribute to a reduction in the level of investment in Norway.

The second identified challenge is the tax distortion between debt and equity finance. The Report briefly discusses neutrality in financing through equal tax treatment of debt and equity finance. The Report then discusses the implications and differences of an ACE and a CBIT model in this context.

The final challenge discussed is base erosion and profit shifting (BEPS). Differences in countries' tax rules create vast opportunities for tax planning, and largely for the benefit of multinational enterprises (MNEs), inter alia through transfer pricing. The Report suggests that BEPS over time may imply a serious threat in maintaining the revenue from the corporate tax base. The Report then acknowledges that a reduction in the formal tax rate may only to some extent address the problem; which indicates a need to consider other supplementing measures. One such measure is the interest deduction limitation rule, made effective from 2014. The rule was introduced to address profit shifting in MNEs. More generally the Report recognises that Norway cannot freely introduce measures against BEPS following international obligations.

Finally the Report mentions the appointment of a Tax Commission in 2013. The Commission's mandate is to review the Norwegian corporate tax system in light of international developments. The Commission shall deliver its report in the autumn of 2014. 
Tema for NSFR-seminaret i 2014 er "Corporate Taxation and the International Challenge". I lys av retningslinjene til de nordiske nasjonalrapportørene, gir vi i denne rapporten en oversikt over prinsipper i det norske selskapsskattesystemet og utviklingstrekk de siste ti årene (punkt 1). I punkt 2 vurderer vi selskapsskatten og internasjonale utfordringer.

\section{Utvikling i skattereglene}

\subsection{Generelle utviklingstrekk}

Norge har siden skattereformen i 1992 hatt et prinsipielt forankret skattesystem med relativt lave skattesatser og brede skattegrunnlag. Norge var, sammen med andre nordiske land, tidlig ute med å redusere selskapsskattesatsen kraftig. Med skattereformen i 1992 ble selskapsskattesatsen redusert fra 50,8 pst. $^{1}$ til 28 pst. Samtidig ble skattegrunnlagene utvidet med sikte på å i størst mulig grad gjenspeile reelle økonomiske forhold. Det ble innført en todelt satsstruktur i inntektsbeskatningen med 28 pst. skatt på all alminnelig inntekt (alle inntekter til personer og selskapsoverskudd) og i tillegg trygdeavgift og ev. toppskatt på personinntekt (lønns-, nærings- og pensjonsinntekter). Alle kapitalinntekter, uavhengig av om de ble opptjent i selskaps- eller personsektoren, ble dermed skattlagt med 28 pst. Siden den gang har skattesatsen på alminnelig inntekt ligget fast på 28 pst. inntil den ble redusert til 27 pst. i 2014.

Før 1992 var bedriftsbeskatningen overbelastet med stadig nye, og til dels motstridende mål. Høye formelle skattesatser og manglende nøytralitet i skattegrunnlagene ga dårlig ressursutnyttelse og svekket skattesystemets omfordelende egenskaper. Etter 1992-reformen har hensynet til effektiv ressursbruk vært førende for utformingen av bedrifts- og kapitalinntektsbeskatningen. Bedrifts- og kapitalinntektsbeskatningens rolle er dermed å skaffe inntekter til det offentlige med minst mulig vridning i ressursbruken, mens fordelingspolitiske mål ivaretas gjennom en progressiv beskatning av personinntekt (arbeidsog pensjonsinntekt) kombinert med formuesskatt. Det er lagt særlig vekt på prinsippene om likebehandling av ulike investeringer, finansieringsformer og organisasjonsformer og symmetrisk behandling av inntekter (gevinster) og utgifter (tap). Dette tilsier blant annet at skattepliktig overskudd så langt som mulig skal fastsettes i samsvar med bedriftsøkonomisk overskudd. "Varige og betydelige" driftsmidler

1 Den reelle skattebelastningen kunne reduseres til 39,1 pst. ved å avsette til konsolideringsfond. 
aktiveres i ulike saldogrupper og avskrives med satser som i prinsippet skal gjenspeile antatt årlig verdifall. Finansdepartementet beregner i 2014 en skatteutgift som følge av at avskrivningssatsene antas å være høyere enn gjennomsnittlig faktisk økonomisk verdifall for hhv. skip, fartøyer, rigger mv. (saldogruppe e), maskiner, personbiler, inventar mv. (saldogruppe $d$, både for den ordinære satsen og for startavskrivning), samt husdyrbygg i landbruket (forhøyet avskrivningssats i saldogruppe $h) .^{2}$

Et av målene med 1992-reformen var at skattesystemet ikke skulle påvirke hvorvidt overskudd i selskapene ble tatt ut eller holdt tilbake. Før reformen var utbytte normalt skattepliktig på mottakerens hånd (statsskatt), mens selskapene bare i begrenset grad fikk fradrag for utdelingen (dvs. delvis dobbeltbeskatning). Det var også egne særregler for beskatning av aksjegevinster. ${ }^{3}$ Skattereglene kunne dermed bidra til innlåsing av kapital i det enkelte selskap, slik at kapitalen ikke ble kanalisert dit den kastet mest av seg.

Etter 1992-reformen innebar godtgjørelsesreglene (innført f.o.m. 1993) at utbytte fra norske selskaper i praksis ikke lenger ble skattlagt på aksjonærens hånd. Ved beregning av gevinster og tap på aksjer $\mathrm{i}$ norske selskaper sikret RISK-reglene (innført f.o.m. 1992) at aksjonæren ble godskrevet den inntekten som var skattlagt i selskapet i aksjonærens eiertid, slik at den delen av gevinsten som skyldes tilbakeholdt overskudd, ikke ble skattlagt. Utbytter og gevinster på aksjer i utenlandske selskaper ble imidlertid beskattet fullt ut (for utbytter ble det gitt kredit for skatt betalt i selskapets hjemland).

For å unngå at aktive eiere kunne få reelle arbeidsinntekter skattlagt som utbytte, ble disse skattlagt etter delingsmodellen. Dette innebar at en beregnet arbeidsavkastningsdel ble skattlagt med en progressiv skatt (trygdeavgift og toppskatt) uavhengig av om overskuddet ble delt ut som utbytte.

Delingsmodellen ble imidlertid gjennom 1990-årene så uthulet at det var enkelt å få reelle arbeidsinntekter skattlagt som utbytte. Hovedmålet med skattereformen i 2006 var å få bukt med dette problemet. Dette ble gjort ved å fjerne selve motivet til slike tilpasninger gjennom å jevne ut de høyeste skattesatsene på eierinntekt og lønnsinntekt, slik at delingsmodellen kunne fjernes. For det første ble høyeste marginalskatt på lønnsinntekt (inkl. arbeidsgiveravgift) redusert fra 64,7 pst. i 2004 til 54,3 pst. i 2006. For det andre ble RISK- og

2 Jf. Prop. 1 LS (2013-2014), vedlegg 1.

3 Aksjer i næring var skattepliktige mens aksjer utenfor næring var fritatt for skatt etter 3 års eiertid, med mindre det dreide seg om betydelig aksjesalg. Ved salg av aksjer utenfor næring der eiertiden var mindre enn 3 år eller aksjesalget var betydelig ble gevinsten skattlagt med 40 pst. 
godtgjørelsesreglene erstattet med aksjonærmodellen, som innebar en skatt på eierinntekter utover en beregnet risikofri avkastning på den investerte kapitalen (skjermingsfradraget). Marginalskatten på eierinntekt på selskapet og eierens hånd ble dermed økt fra 28 pst. til 48,16 pst. ${ }^{4}$ Ubenyttet skjermingsfradrag fremføres med rente mot framtidige utbytter og gevinster på den enkelte aksje. Skjermingen av risikofri avkastning skal forhindre at utbytteskatten øker avkastningskravet på norsk egenkapital, noe som anses å være spesielt viktig for nystartede og små selskaper som har begrenset tilgang på kreditt, tilbakeholdt overskudd og kapital fra utlandet.

For selskaper ble RISK- og godtgjørelsesreglene erstattet med fritaksmetoden (innført f.o.m. 2004), som innebærer at utbytter og aksjegevinster mellom selskaper er fritatt for skatt. Selskapsoverskudd skattlegges dermed én gang i selskapssektoren, og én gang når det tas ut av selskapssektoren (den delen som overstiger en avkastning tilsvarende risikofri rente). Mens RISK- og godtgjørelsesreglene kun gjaldt aksjeinntekter fra norske selskaper, og dermed hadde en usikker side mot EØS-avtalen, ble fritaksmetoden også gjort gjeldende for aksjeinntekter til og fra EØS-stater. Dette skulle sikre at Norges forpliktelser etter EØS-avtalen ble ivaretatt. Fritaksmetoden gjelder også aksjeinntekter fra land utenfor EØS, men ikke for porteføljeinvesteringer (mindre enn 10 pst. eierandel) og ikke for selskaper i lavskatteland.

\subsection{Sammensetningen av skatte- og avgiftsinntekter, og immobile skattegrunnlag}

Den største delen av skatte- og avgiftsinntektene i Norge kommer fra skatt på alminnelig inntekt for personer (22 pst.), merverdiavgift (19 pst.), arbeidsgiveravgift (13 pst.) og petroleumsskatt (16 pst.), jf. figur 1. Selskapsskatten fra fastlandsbedriftene utgjør 6 pst. av de samlede skatte- og avgiftsinntektene. Sammenlignet med andre OECD-land skiller Norge seg ut ved betydelige inntekter fra skatt på grunnrenter, samt at en relativt lav andel av skatte- og avgiftsinntektene kommer fra skatt på eiendom og formue. Beskatningen av grunnrenter og fast eiendom i Norge er nærmere omtalt i avsnittene nedenfor.

428 pst. $+(1-0,28) * 28$ pst. $=48,16$ pst.

176 Martin Børresen, Marius Pilgaard E Marie Bjørneby 


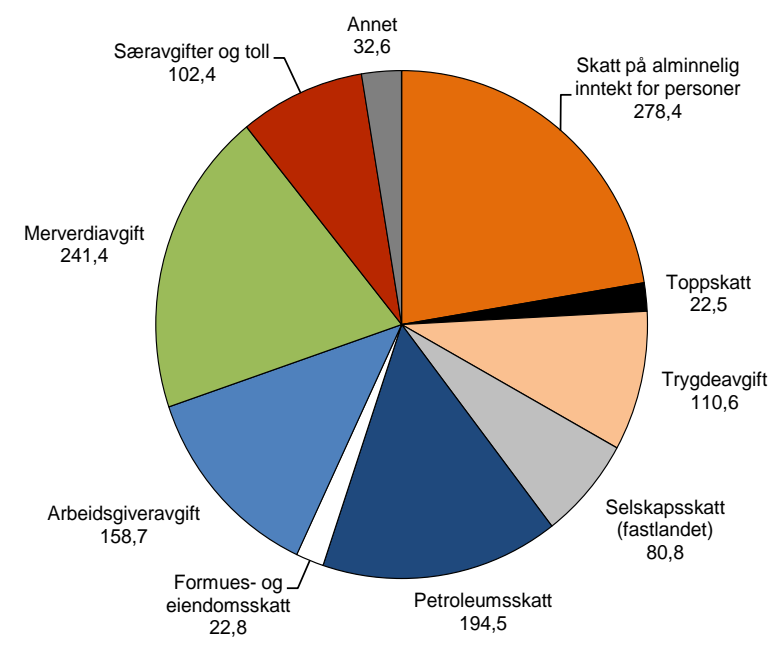

Figur 1 Påløpte skatter og avgifter. Anslag for 2013. Mrd. kroner

Kilde: Finansdepartementet.

\subsubsection{Beskatning av grunnrenter}

Petroleumsselskapene som opererer på norsk kontinentalsokkel utnytter en knapp ressurs. Dette gir grunnlag for høyere avkastning enn i andre sektorer. Petroleumsskattesystemet skal sikre at denne ekstraavkastningen, grunnrenten, tilfaller samfunnet som ressurseier.

I tillegg til skatt på alminnelig inntekt (27 prosent), skal petroleumsselskapene derfor svare en særskatt til staten på 51 prosent. Den samlede skattesatsen på 78 prosent har ligget fast siden skattereformen i 1992. Samtidig har petroleumsskattesystemet blitt mer nøytralt i denne perioden. Imidlertid mener blant annet Petroleumsskatteutvalget (NOU 2000:18) at investeringer på norsk sokkel blir behandlet for sjenerøst i petroleumsskattesystemet gjennom høye avskrivninger og fradrag for friinntekt og rentekostnader.

Ved kraftskattereformen i 1996 ble det innført en grunnrenteskatt på vannkraftverk av en viss størrelse. Det er senere foretatt justeringer som skal gjøre grunnrenteskatten mer nøytral.

Skatt på grunnrenteinntekt kommer i tillegg til skatt på alminnelig inntekt. Fra 1996 til 2006 var skattesatsen på grunnrenteinntekt 27 prosent. Skattesatsen ble økt til 30 prosent i 2007 og til 31 prosent i 2014. Samlet skattesats på vannkraftproduksjon er dermed 58 prosent. 
I tillegg kan kommunene skrive ut eiendomsskatt på vannkraftanlegg (se under).

\subsubsection{Beskatning av fast eiendom}

Norge er ett av få land med formuesskatt, men til gjengjeld har mange land vesentlig høyere skatt på eiendom enn Norge. Arveavgiften ble fjernet i Norge med virkning fra 2014. Når en ser på summen av skatt på eiendom, formue og arv som andel av samlede skatteinntekter, ligger Norge godt under OECD-gjennomsnittet.

Eiendomsskatten er en kommunal skatt. Kommunestyret avgjør om det skal skrives ut eiendomsskatt i kommunen. Fra 2007 er kommunen gitt flere utskrivingsalternativer. Eksempelvis kan kommunen velge å skrive ut eiendomsskatt i hele kommunen, eller kun på næringseiendom.

Kommunen kan skrive ut eiendomsskatten med 2 til 7 promille av takstgrunnlaget. Skattesatsen har ligget fast siden innføringen av eigedomsskattelova i 1975. Eiendomsskattepliktige eiendommer takseres til antatt omsetningsverdi. Kommunen har imidlertid anledning til å benytte en felles reduksjonsfaktor i takstene. Det gis ikke fradrag for gjeld (bruttoskatt).

Personlige skattytere betaler formuesskatt på 1 pst. av skattepliktig nettoformue (samlet bruttoformue fratrukket gjeld) som overstiger 1 mill. kroner i 2014. Eiendelene skal i utgangspunktet verdsettes til markedsverdi. Fast eiendom verdsettes imidlertid betydelig lavere, selv om verdsettingen er økt en rekke ganger de siste årene. Det er blant annet innført nye metoder for verdsetting av bolig og næringseiendom som i større grad skal reflektere eiendommenes antatte omsetningsverdi. I 2014 verdsettes primærbolig til 25 pst., mens sekundærbolig og næringseiendom verdsettes til 60 pst. av antatt omsetningsverdi. Økt formuesbeskatning av fast eiendom er kombinert med større bunnfradrag og reduserte satser.

\subsection{Særlige regler i selskapsskatten}

I punktene under gis en kort omtale av sentrale regler i det norske selskapskattesystemet. Behandlingen følger den tematiske inndelingen i retningslinjene utarbeidet av NSFR.

\subsubsection{Fritaksmetoden}

Fritaksmetoden i skatteloven § 2-38 innebærer at selskaper som hovedregel er unntatt fra skatt på utbytte og gevinst på aksjer, samtidig som det ikke gis fradragsrett for tap. Hensikten er å hindre kjedebeskatning i selskapssektoren. Fritaksmetoden gjelder ikke for porteføljeinvesteringer (under 10 pst. eier- og stemmeandel) i selskaper hjem- 
mehørende utenfor EØS, og er generelt avgrenset mot selskaper hjemmehørende i lavskatteland utenfor EØS.

Etter innføringen av fritaksmetoden i 2004 er det gjort enkelte justeringer i reglene. I 2008 ble det innført en regel om at norske selskaper skal inntektsføre tre prosent av inntekter som omfattes om fritaksmetoden. 3-prosentregelen kommer ikke til anvendelse i konsernforhold pga. konsernbidragsreglene, og etter en lovendring i 2011 gjelder den heller ikke for aksjegevinster (pga. administrative hensyn). 3-prosentregelen gjelder for utenlandske selskaper som driver skattepliktig virksomhet i Norge. Inntektsføring etter 3-prosentregelen gir en sjablongmessig reversering av fradrag for kostnader knyttet til ervervet av den fritatte inntekten.

Fritaksmetoden er også strammet inn overfor selskaper i EØS for å motvirke omgåelser. Med virkning fra 2008 ble fritaket for kildeskatt på utbytte for selskaper hjemmehørende i et EØS-land, gjort betinget av at selskapsaksjonæren er reelt etablert og driver reell økonomisk aktivitet i et EØS-land. For utbytte og gevinst på aksjer i selskap hjemmehørende i et lavskatteland i EØS er det innført tilsvarende vilkår om at selskapet er reelt etablert mv. i et EØS-land. Endringene ble gjennomført etter EU-domstolens avgjørelse i sak C-196/04 Cadbury Schweppes.

For å hindre tilpasninger knyttet til forskjellen mellom beskatningen av aksjeinntekter etter fritaksmetoden og de alminnelige reglene om fradragsrett ved tap på fordring, ble det i 2011 vedtatt en regel om avskjæring av fradragsrett ved tap på fordring mellom nærstående selskap.

For å avverge kjedebeskatning i selskapssektoren anses fritaksmetoden langt enklere å administrere enn for eksempel regler om kredit for underliggende selskapsskatt (utenfor fritaksmetodens anvendelsesområde har skatteloven regler om kredit for underliggende selskapsskatt i § 16-30). Innføringen av fritaksmetoden (og aksjonærmodellen for fysiske personer) innebar forenklinger for ligningsmyndigheter og skattytere, ved at en kunne oppheve RISK- og godtgjørelsessystemet.

\subsubsection{Kildeskatter}

Norge har ikke internrettslig hjemmel til å ilegge kildeskatt på renter og royalty. For utbytte som deles ut fra norsk selskap, er det hjemmel til å ilegge kildeskatt både for aksjonær som er personlig skattyter og selskapsaksjonær. Skattesatsen er 25 pst., men er gjerne satt ned i skatteavtaler (i de fleste avtalene er satsen 15 pst.). Det er utbyttets bruttobeløp som er skattepliktig. Selskapsaksjonær som er reelt etablert mv. i en EØS-stat, vil imidlertid være fritatt for kildeskatt på utbytte fordi fritaksmetoden kommer til anvendelse, jf. ovenfor. 


\subsubsection{Skatteavtaler (kildeskatter)}

Norge har inngått mer enn 80 skatteavtaler som skal forebygge internasjonal dobbeltbeskatning mv. I overensstemmelse med at det ikke er etablert en internrettslig hjemmel til å ilegge kildeskatt på rente- og royaltybetalinger, har norsk skatteavtalepolitikk vært bostedsbeskatning for slike inntekter. For utbytte fordeler norske skatteavtaler normalt beskatningsretten mellom hjemstat og kildestat. Norge benytter kreditmetoden for å avverge dobbeltbeskatning.

\subsubsection{Begrensning av rentefradrag}

Med virkning fra inntektsåret 2014 er det innført regler om begrensning av rentefradrag ved lån mellom nærstående parter. Regelen innebærer at fradrag for rentekostnader som overstiger 30 pst. av en særskilt fastsatt resultatstørrelse, avskjæres. Det er bare fradrag for renter betalt til nærstående (interne renter) som eventuelt skal begrenses. Renter betalt til uavhengig tredjepart (eksterne renter) er ikke selv gjenstand for avskjæring, men kan fortrenge fradrag for interne renter.

Reglene skal redusere insentivene for at flernasjonale konsern plasserer en høy andel av konsernets gjeld i konsernselskap hjemmehørende i Norge, mens renteinntekter mv. blir kanalisert til konsernselskap hjemmehørende i land med lav beskatning. Blant annet av hensyn til EØS-avtalen omfatter reglene også låneforhold mellom selskaper hjemmehørende i Norge.

Ved beregning av rentefradragsrammen tas det utgangspunkt $i$ skattyterens alminnelige inntekt (eller årets underskudd) før eventuell begrensning i rentefradraget. Netto rentekostnader og skattemessige avskrivninger skal tilbakeføres i dette grunnlaget. Rammen for rentefradraget skal utgjøre 30 pst. av denne resultatstørrelsen. Beregningsgrunnlaget innebærer en skattemessig tilnærming til det regnskapsmessig EBITDA (Earnings before interest, tax and depreciation/ amortization - Resultat før renter, skatt og avskrivninger).

Netto rentekostnader omfatter i utgangspunktet alle rentekostnader og renteinntekter som ligger innenfor det alminnelige, skatterettslige rentebegrepet.

Med interne renter menes rentekostnader betalt til nærstående person, selskap eller innretning. For å anses som nærstående part kreves direkte eller indirekte eierskap eller kontroll med minst 50 pst. Nærstående part kan være hjemmehørende i Norge eller i utlandet. For å begrense omgåelsesmuligheter, er også renter på visse lån til eksterne parter omfattet av regelen (såkalte "back-to-back"-lån og lån med sikkerhetsstillelse fra nærstående).

Det gjelder et terskelbeløp for rentefradragsbegrensningen på 5 mill. kroner (eksterne og interne netto rentekostnader). 
Fradragsbegrensningen beregnes individuelt for hver enkelt skattyter. Avskåret rentefradrag kan framføres til fradrag i de ti påfølgende inntektsårene.

Regelen om begrensning av rentefradrag omfatter aksjeselskap og øvrige selskap og innretninger som lignes som eget skattesubjekt (selskapsligning). Videre omfattes deltakerlignede selskap og NOKUS-selskap, samt selskap og innretninger som har begrenset skatteplikt til Norge. Finansinstitusjoner er unntatt fra begrensningsregelen.

\subsubsection{CFC-regler}

Skatteloven har i §\$10-60 flg. særlige regler om løpende beskatning av deltakere i norsk-kontrollerte utenlandske aksjeselskap og likestilte selskap eller sammenslutninger mv. som er hjemmehørende i lavskatteland (NOKUS-reglene). Hovedbegrunnelsen bak reglene er å motvirke skattemotivert kapitalflukt til lavskatteland. For å motvirke kapitalflukt er reglene innrettet slik at de skal likebehandle norske skattyteres investeringer i Norge og lavskatteland (kapitaleksportnøytralitet). Norsk kontroll av utenlandsk selskap mv. anses som hovedregel å foreligge hvor minst halvparten av selskapets andeler eller kapital direkte eller indirekte eies eller kontrolleres av norske skattytere. Som lavskatteland regnes land hvor den alminnelige inntektsskatt på selskapets samlede overskudd utgjør mindre enn to tredjedeler av skatten som ville blitt ilignet i Norge.

Det foretas ikke NOKUS-beskatning av norske eiere i selskaper hjemmehørende i land Norge har skatteavtale med, med mindre selskapets inntekter hovedsakelig er av passiv karakter. Etter en lovendring i 2007 kommer NOKUS-reglene ikke til anvendelse hvis selskapet mv. er reelt etablert og driver reell økonomisk aktivitet i et lavskatteland i EØS. Det ble samtidig etablert et vilkår knyttet til dokumentasjon og verifiseringen av denne. Regelendringen ble gjennomført etter EU-domstolens avgjørelse i sak C-196/04 Cadbury Schweppes.

Etter en lovendring i 2013 gis fritaksmetoden nå tilsvarende anvendelse når personlige deltakere lignes for NOKUS-selskapets inntekt. Formålet med endringen er å unngå kjedebeskatning av norske personlige deltakere. Manglende anvendelse av fritaksmetoden i disse tilfellene hadde også en usikker side mot EØS-retten.

Finansdepartementet varslet i budsjettet for 2013 en generell gjennomgang av NOKUS-reglene.

\subsubsection{Internprising}

Inntekt eller formue kan fastsettes ved skjønn dersom denne er redusert på grunn av direkte eller indirekte interessefellesskap med annen person, selskap eller innretning, jf. skatteloven § 13-1. Ved skjønnet skal inntekt eller formue fastsettes som om interessefellesskapet ikke 
hadde foreligget (armlengdeprinsippet). Bestemmelsen gjelder både mellom nærstående parter innad i Norge og hvor en part er hjemmehørende i utlandet. Bestemmelsen gjelder flere former for interessefellesskap, ikke bare at partene er underlagt samme kontroll i et konsern.

OECDs retningslinjer for hvordan armlengdeprinsippet skal praktiseres av skattemyndighetene og flernasjonale foretak (OECD Transfer Pricing Guidelines for Multinational Enterprises and Tax Administrations) er gitt virkning i norsk internrett.

Fra 2008 innførte Norge særskilte oppgave- og dokumentasjonsregler knyttet til kontrollerte transaksjoner mellom nærstående parter. Dokumentasjonsreglene er basert på anbefalinger fra OECD.

Skattytere som sammen med andre nærstående parter har mindre enn 250 ansatte og som enten har en salgsinntekt som ikke overstiger 400 mill. kroner eller en balansesum som ikke overstiger 350 mill. kroner, er som hovedregel unntatt dokumentasjonsplikten.

\subsubsection{Utflytting av eiendeler og forpliktelser mv. fra norsk beskatnings- område}

Overføring av en eiendel mellom to skattesubjekter utløser normalt realisasjonsbeskatning. Grenseoverskridende disposisjoner kan imidlertid gjennomføres uten at eiendelene anses realisert etter hovedreglene om realisasjon. For eksempel kan en norsk filial av et utenlandsk selskap fysisk flytte et driftsmiddel fra Norge til hovedkontoret i utlandet. Det vil uthule det norske skattefundamentet dersom latente gevinster opparbeidet her ikke blir realisert (eller på annen måte gjort opp) ved utflyttingen, eksempelvis forut for et planlagt salg.

I 2008 innførte Norge regler om skatteplikt for gevinst på eiendeler og forpliktelser som tas ut av norsk beskatningsområde ${ }^{5}$. Slik utflytting utløser skatteplikt for gevinst som om eiendelen var realisert siste dag før utflyttingen. Bestemmelsene omfatter også eiendeler mv. som flyttes ut av Norge gjennom skattefri utflytting av selskap og virksomhet (skattefri fusjon eller fisjon mv.). Bestemmelsen suppleres av enkelte spesialregler.

Fradrag for latent tap kan kreves av skattyter som er skattepliktig til Norge eller skattemessig hjemmehørende i en EØS-stat på utflyttingstidspunktet.

For omsetningsgjenstander og immaterielle eiendeler forfaller skatten umiddelbart til betaling. Dette gjelder også flytting til en EØS-stat.

5 Begrepet "norsk beskatningsområde" innebærer ikke at det aktuelle objektet fysisk må befinne seg i Norge, men at inntekter og kostnader tilknyttet eiendelen mv. er skattepliktig hit. Dette reguleres av norske interne skatteregler om alminnelig eller begrenset skatteplikt, og av skatteavtaler. 
Skattyter som er hjemmehørende i Norge eller annen EØS-stat gis av likviditetshensyn rett til utsatt betaling av utlignet og forfalt skatt som utløses ved uttak av fysiske driftsmidler, finansielle eiendeler og forpliktelser. Det skal beregnes renter på skattebeløpet. Etter en konkret vurdering av hvilken risiko det er for at uttaksskatten ikke vil blir betalt når vilkårene for utsettelse ikke lenger er til stede, kan skattemyndighetene kreve sikkerhetsstillelse for skattekravet, inkludert renter.

Av administrative hensyn skal det beregnes skatt på gevinst og tap på fysiske driftsmidler på 5 millioner kroner eller mindre (terskelbeløp). Øvrige objekter vurderes samlet per gruppe, med en terskel på 1 million kroner i løpet av inntektsåret.

EU-domstolen har i flere saker akseptert at en stat på visse vilkår kan skattlegge urealiserte gevinster ved uttak fra opprinnelsesstatens beskatningsområde til en annen medlemsstat, blant annet C-371/10 National Grid Indus.

I nasjonalbudsjettet for 2014 varsler Finansdepartementet justeringer i reglene om uttak av eiendeler mv. fra norsk beskatningsområde som følge av utviklingen i EU-/EØS-retten. Se blant annet EUdomstolens avgjørelse 18. juli 2013 i sak C-261/11 Kommisjonen mot Danmark og avgjørelse 23. januar 2014 i sak C-164/12 DMC Beteiligungsgesellschaft $\mathrm{mbH}$.

\subsubsection{Fritak for skatteplikt for petroleumsvirksomhet $i$ utlandet}

Det norske skattesystemet bygger på globalinntektsprinsippet og kreditprinsippet. Dette betyr at inntekter i utgangspunktet er skattepliktige hit uavhengig av hvor i verden de er opptjent, men at Norge som hjemstat gir fradrag (ordinær kredit) i norsk skatt for skatt betalt i utlandet på inntekter med utenlandsk kilde.

Fra 2013 er inntekt ved utvinning av petroleum i utlandet fritatt fra skatteplikt. Tilsvarende gis det ikke fradragsrett for kostnader og tap knyttet til slik inntekt. Innføring av et territorialprinsipp for petroleumsvirksomhet i utlandet ble innført for å hindre uthuling av det norske skattegrunnlaget. 
Uten slike regler (eller andre særtiltak ${ }^{6}$ ) kan oljeselskap hjemmehørende i Norge få fradrag for store deler av kostnadene i skattegrunnlaget for landbasert virksomhet i Norge. Samtidig vil Norge kun få beskjedne inntekter fra utvinningsvirksomheten i utlandet. Dette skyldes den spesielle inntekts- og kostnadsprofilen til denne næringen, høy naturressursbeskatning i kildelandet og måten det norske skattesystemet virker samlet sett.

\subsubsection{Ulovfestet gjennomskjæring}

Den ulovfestede omgåelsesregelen er et særskilt rettsgrunnlag som gir skattemyndighetene mulighet til å omklassifisere en disposisjon mv. for skatteformål. Normens funksjon er i praksis å trekke grensen mellom akseptabel skatteplanlegging og uakseptabel skatteomgåelse, og den supplerer lovfestede skatteregler og generelle prinsipper for lovtolkning. Normens innhold utledes av praksis fra Høyesterett. Etter denne rettspraksisen skal vurderingen være todelt: Grunnvilkåret går ut på at det hovedsakelige formålet bak disposisjonen må ha vært å spare skatt (skattemotivet skal vurderes subjektivt). Videre må disposisjonen ut fra en totalvurdering være stridende mot skattereglenes formål.

Slik normens innhold er fastlagt gjennom praksis og dens svært skjønnspregete vurderingstemaer, kan skattemyndighetene i liten grad basere seg på normen for å motvirke uthuling av skattegrunnlag mer generelt. Normen bør derfor virke ved siden av andre mer treffsikre regler. Omgåelsesnormen er anvendelig også overfor grenseoverskridende disposisjoner, men det kan tenkes at den må tolkes restriktivt i enkelte sammenhenger for å hindre konflikt med EØSavtalen mv.

Utviklingen i normens innhold, der vurderingen av grunnvilkåret om skattemotiv har gått fra å være underlagt en objektiv bedømmelse til at det nå skal være en ren subjektiv vurdering, har på ny aktualisert spørsmålet om normen bør lovfestes.

Ved siden av den ulovfestede omgåelsesregelen er det lovfestet en særskilt omgåelsesregel i skatteloven § 14-90, rettet mot skattemotivert utnyttelse av reglene om skattefri omorganisering.

\subsubsection{Informasjonsutveksling}

Norge har siden 2006 inngått ca. 40 særskilte informasjonsutvekslingsavtaler, hovedsakelig med såkalte skatteparadis. Avtalene har

6 I høringsnotatet ble det foreslått flere alternative tiltak, herunder regler som avskjærer muligheten for samordning mellom norsk landbasert virksomhet og utenlandsk petroleumsutvinningsaktivitet. Dette ble ansett som et effektivt tiltak, men administrativt krevende. 
blitt inngått som ledd i et felles nordisk samarbeid i regi av Nordisk ministerråd, der statene har gått sammen om å fremforhandle avtaler. Utveksling av informasjon på bakgrunn av avtalene skjer etter anmodning. Det gjenstår å se hvor effektive disse avtalene blir i praksis.

I tillegg har de fleste norske skatteavtaler egne bestemmelser om informasjonsutveksling etter mønster fra OECDs modellavtale, men rekkevidden til disse er normalt mer begrenset. Norge er også part i to multilaterale avtaler om administrativ bistand i skattesaker (Europarådet/OECD og Den nordiske avtalen).

Norge inngikk videre i 2013 en avtale om gjennomføring av Foreign Account Tax Compliance Act (FATCA). Innenfor sitt virkeområde innebærer avtalen automatisk informasjonsutveksling mellom norske og amerikanske skattemyndigheter. Norge deltar i det internasjonale arbeidet for automatisk informasjonsutveksling og er med i Global Forum on Transparency and Exchange of Information for Tax Purposes.

\section{Selskapsskatten og internasjonale utfordringer}

\subsection{Virkning på investeringer}

All erfaring fra oppryddingen i næringsbeskatningen gjennom 1992reformen tilsier at generelle, gode skattevilkår uten særordninger gir det beste utgangspunktet for at næringslivet satser der avkastningen er høyest for samfunnet.

Siden skattereformen i 1992 har all normalavkastning på kapitalen blitt skattlagt med samme sats, uavhengig av om inntekten er opptjent i eller utenfor næringsvirksomhet. Det er videre lagt vekt på at skattemessig overskudd i størst mulig grad skal samsvare med det reelle økonomiske overskuddet. Selv om dette ikke kan sies å være fullt ut oppfylt i dagens skattesystem, er det mye som tyder på at oppryddingen i 1992-reformen har bidratt til mer effektiv ressursbruk i norsk økonomi. Større grad av samsvar mellom investeringenes bedriftsøkonomiske (etter skatt) og samfunnsøkonomiske (før skatt) lønnsomhet førte til markert økning i avkastningen av realkapitalen i markedsrettet virksomhet i perioden etter skattereformen. Figur 2 viser at skatteinntektene fra selskapssektoren som andel av BNP for Fastlands-Norge vokste kraftig etter 1992-reformen. Dette til tross for at skattereformen i 1992 isolert sett viste seg å innebære en lettelse for 
selskapene. Mye av økningen kan trolig tilskrives høykonjunkturen i perioden. En annen mulig årsak til økningen kan være at inntekter i større grad enn tidligere opptjenes i selskaper. Det er likevel grunn til å tro at deler av økningen skyldes at skattereformen bidro vesentlig til $ø k t$ kapitalavkastning før skatt siden kapitalen etter hvert fikk en bedre samfunnsøkonomisk anvendelse. ${ }^{7}$

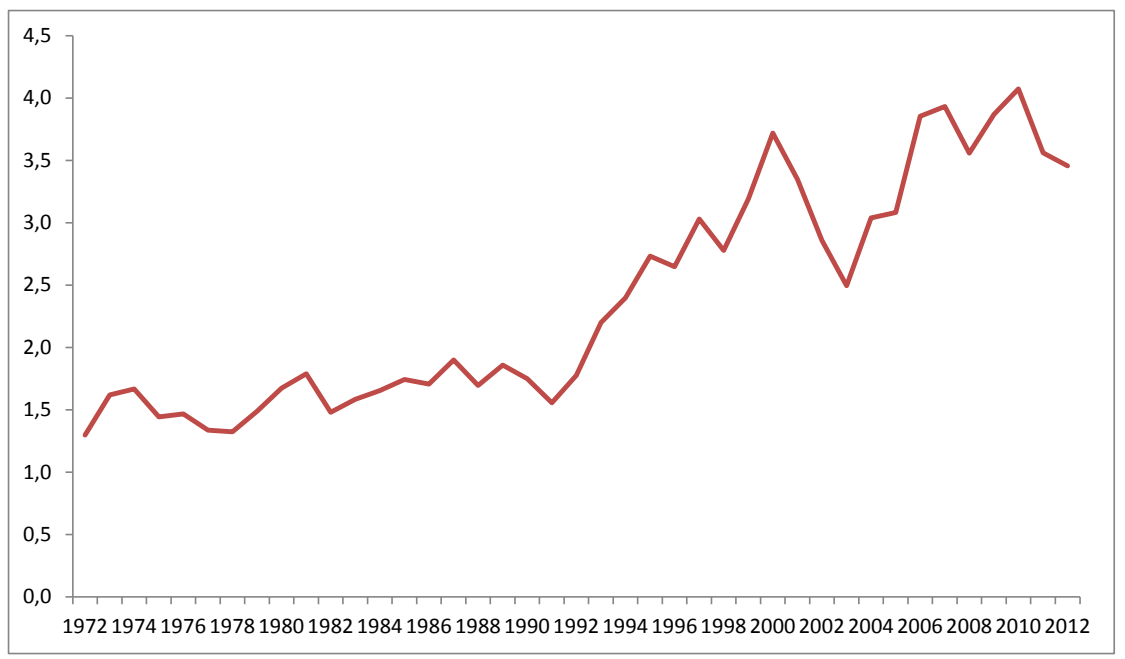

Figur 2 Selskapsskatt som andel av BNP i

Fastlands-Norge. 1972-2012.

Kilde: Statistisk sentralbyrå.

Selv om det er lagt stor vekt på nøytralitet i selskaps- og kapitalbeskatningen ved at kapitalavkastning $i$ alle innenlandske anvendelser $i$ størst mulig grad beskattes likt, vil ulik beskatning av selskapsinntekt ute og hjemme skape vridninger i investeringene. For utenlandske investorer vil den norske selskapsskatten virke som en ren kildebasert skatt som øker avkastningskravet på å investere i Norge. ${ }^{8}$ Det samme vil gjelde for norske investorer dersom de kan investere i utlandet til en lavere effektiv skattesats enn i Norge. I en åpen økonomi vil dessuten selskapsskatten kunne ha betydning for lokalisering av investeringer som gir mobile renprofitter (selv om avkastningskravet er upåvirket).

7 Jf. Skauge-utvalget (NOU 2003: 9).

8 Forutsatt at norsk selskapsskatt ikke fullt ut blir kreditert i investorens hjemland. 
Selskapsskattesatsen i Norge ligger i dag høyere enn skattesatsen i mange land Norge ofte sammenlignes med, herunder de andre nordiske landene. Flere land har nylig gjennomført eller varslet ytterligere reduksjoner. Satsforskjellen mellom Norge og nabolandene er derfor økende. I kombinasjon med brede skattegrunnlag, herunder relativt lave avskrivningssatser, bidrar dette til at den effektive selskapsbeskatningen i Norge i dag er høyere enn i mange andre sammenlignbare land. Dette kan over tid bidra til at investeringsnivået i Norge reduseres.

Skatt en kun én av mange faktorer som kan påvirke hvilket land man velger å investere i. Nærhet til markeder, tilgang på kvalifisert arbeidskraft, effektiv offentlig administrasjon, god infrastruktur, politisk stabilitet og fravær av korrupsjon har trolig større betydning for hvor attraktivt det er å investere i et land. En rekke forhold, blant annet tilgang på kvalifisert arbeidskraft og politisk stabilitet, trekker i retning av at investeringsvilkårene er gode i Norge sammenlignet med mange andre land. Dette underbygges av at Norge rangeres høyt i flere internasjonale undersøkelser som sammenligner vilkårene for å investere og starte og drive virksomhet i ulike land. ${ }^{9}$

Figur 3 viser utviklingen i bruttoinvesteringer i fast realkapital i hhv. alle næringer og i Fastlands-Norge i perioden 1990-2013. Gode investeringsvilkår har over tid gitt grobunn for en høy levestandard i Norge. Investeringene i olje- og gassvirksomhet har særlig bidratt til dette. Det er imidlertid en økende bekymring for at det høye kostnadsnivået kan skape utfordringer for investeringsvilkårene framover, noe blant annet Holden III-utvalget (NOU 2013:13) påpekte. Holden III-utvalget framhevet at den kostnadsmessige konkurranseevnen ikke bør svekkes dersom en vil redusere risikoen for en sterk nedbygging av konkurranseutsatt sektor.

9 Jf. bl.a. "The Global Competitiveness Report 2013-2014" fra World Economic Forum og "Doing Business 2014" fra Verdensbanken. 


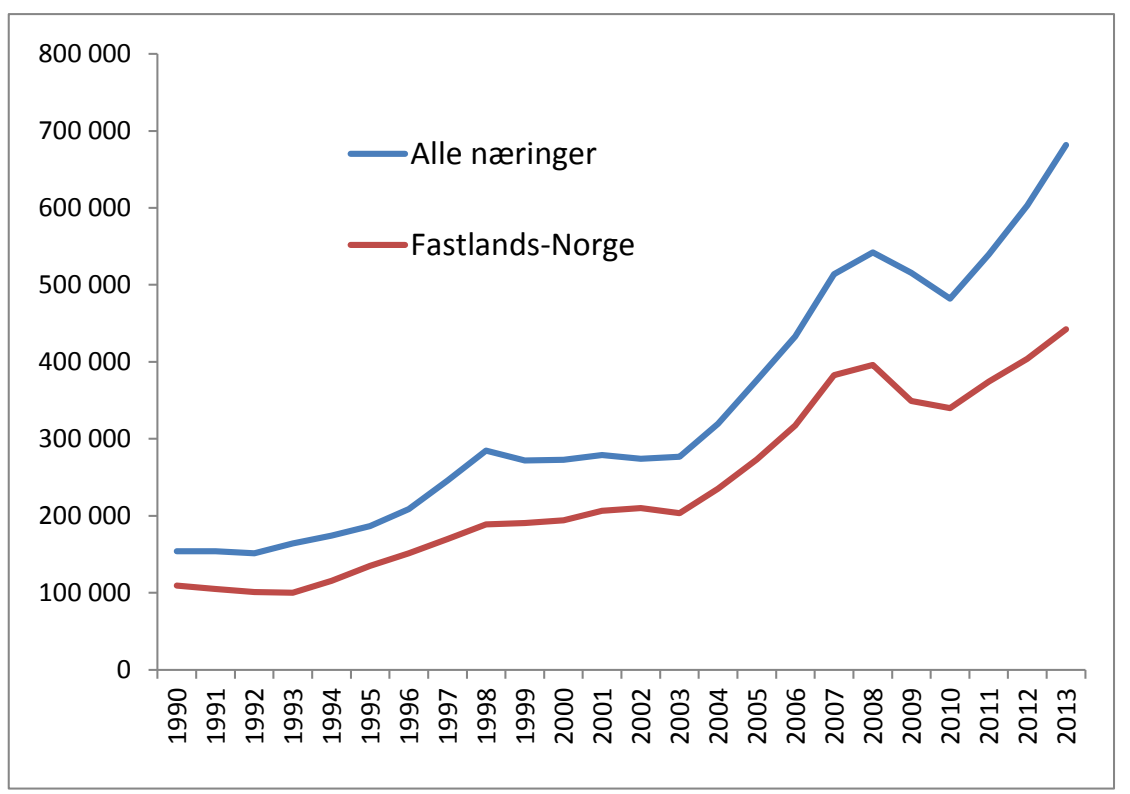

Figur 3 Bruttoinvesteringer i fast realkapital. Løpende priser. Mill. kroner

Kilde: Statistisk sentralbyrå.

Stoltenberg II-regjeringen la i Revidert nasjonalbudsjett 2013 fram forslag til en vekstpakke som skulle bedre konkurransekraften, øke lønnsomheten og styrke investeringene i fastlandsbedriftene. Forslaget innebar blant annet en reduksjon i selskapsskattesatsen fra 28 til 27 pst., samt innføring av 10 pst. startavskrivning for maskiner og andre driftsmidler i saldogruppe d. (vedtatt med virkning f.o.m. 2014). Særskatten på petroleumsutvinning og grunnrenteskatten for vannkraftanlegg ble økt med 1 prosentpoeng, slik at den samlede marginalskatten for grunnrentenæringene ble uendret. Dette skulle bidra til å dempe todelingen i norsk økonomi, dvs. mellom oljerelaterte og andre næringer, jf. Meld. St. 2 (2012-2013): “Fastlandsøkonomien trekkes opp av sterk vekst i etterspørselen fra oljevirksomheten. Høy lønnsvekst og en gradvis styrking av kronen har imidlertid løftet kostnadsnivået i Norge. Det gjør mange eksportbedrifter sårbare i en situasjon med svak etterspørsel ute. Denne utviklingen har bidratt til en todeling av norsk økonomi, der næringer som leverer til oljevirksomheten, har vokst sterkere enn tradisjonelle eksportrettede næringer. For å dempe denne todelingen foreslår Regjeringen skattetiltak for næringslivet i Fastlands-Norge og en forbedring av petroleumsskattereglene."

Økt internasjonalisering, herunder økt kapitalmobilitet tilsier isolert sett redusert selskapsskatt og økt skattlegging av kapital på de 
personlige eiernes hånd og mindre mobile skattegrunnlag. Skattereformen 2006 med innføringen av aksjonærmodellen for personlige aksjonærer og fritaksmetoden for selskaper kan tilsynelatende se ut til å gå i denne retningen. I praksis bidro imidlertid disse reglene til at norske investorer i større grad enn tidligere kan oppnå lavere skatt ved å investere i utlandet sammenlignet med å investere i Norge. Dette skyldes at de tidligere RISK- og godtgjørelsesreglene kun gjaldt aksjer i norske selskaper, mens fritaksmetoden (med visse begrensninger) og aksjonærmodellen også gjelder ved investeringer i utlandet. Hensynet til insentivene til å investere i Norge kan tilsi at nordmenns investeringer i utlandet skattlegges minst på samme nivå som investeringer $\mathrm{i}$ utlandet. Det er imidlertid begrenset handlingsrom innenfor EØS-avtalen til å stramme inn i beskatningen av aksjeinntekter fra utlandet uten å foreta tilsvarende innstramminger for aksjeinntekter fra norske selskaper. En innstramming kun for aksjeinntekter fra land utenfor EØS vil kunne ha begrenset virkning som følge at slike aksjeinntekter kan kanaliseres via selskaper i EØS. Dagens regler anses dessuten å være langt mindre administrativt krevende enn en kreditmetode for underliggende selskapsskatt.

\subsection{Likebehandling av gjeld og egenkapital}

Selskapsskatten innebærer isolert sett en favorisering av gjeld framfor egenkapital. Kapitalkostnaden ved gjeldsfinansiering (rentekostnaden) er som hovedregel fradragsberettiget, mens kapitalkostnaden ved egenkapitalfinansiering (alternativkostnaden ved å binde egenkapitalen) ikke kan fradragsføres. Det gjør at selskapsskatten isolert sett øker avkastningskravet ved egenkapitalfinansiering, mens avkastningskravet ved gjeldsfinansiering kan reduseres som følge av fradrag for nominelle rentekostnader.

Skattemessig favorisering av gjeld kan ha flere uheldige virkninger. For det første kan investeringer som avhenger av egenkapitalfinansiering, fortrenges av investeringer som kan finansieres med gjeld på grunn av forskjellen i kapitalkostnadene ved gjeld og egenkapital. Investeringssammensetningen kan dermed bli påvirket. Det må forventes at det særlig er virksomheter i oppstartsfasen som er henvist til egenkapitalfinansiering, og at forskjellsbehandlingen av gjeld og egenkapital derfor særlig går ut over slik virksomhet. For det andre kan selskapene bli stimulert til å øke sin gjeldsgrad og dermed øke sin konkursrisiko. For det tredje gir forskjellsbehandlingen av gjeld og egenkapital muligheter for overskuddsflytting, jf. avsnitt 2.3.

I det norske skattesystemet er gjeldsfavoriseringen i selskapsskatten forsøkt motvirket av en motsvarende skjevhet mellom gjeld og egenkapital i personbeskatningen. På personlig hånd beskattes gjeldsrenter fra første krone, mens avkastning på egenkapital opptil en risi- 
kofri rente (skjermingsrente) er skattefri. Utformingen av aksjonærmodellen, der skjermingen er knyttet til den enkelte aksje og ubenyttet skjerming går tapt etter realisasjon av aksjen, gjør imidlertid at personbeskatningen ikke fullt ut motvirker gjeldsfavoriseringen i selskapsskatten. I en åpen økonomi, der den marginale investoren kan være utenlandsk, kan den norske personbeskatningen uansett ikke sikre finansieringsnøytralitet. Dersom kapitalen er perfekt mobil, dvs. at avkastningskravet etter skatt er gitt fra det internasjonale kapitalmarkedet, kan det argumenteres for at det kun er selskapsskatten som har betydning for avkastningskravet før skatt ved å investere i Norge, også for norske investorer.

På denne bakgrunn kan det argumenteres med at finansieringsnøytralitet kun kan oppnås ved likebehandling av gjeld og egenkapital i selskapsskatten. Dette kan oppnås ved å gi fradrag for normalavkastning på egenkapitalen på selskapets hånd ( $\mathrm{ACE})$, slik at selskapene får fradrag for kostnader ved både lånefinansiering og egenkapitalfinansiering. En annen måte å fjerne forskjellsbehandlingen på er å nekte selskapene å fradragsføre renteutgifter (CBIT).

Både ACE- og CBIT-modellen kan sies å sikre finansieringsnøytralitet, men for øvrig er virkningen av de to modellene svært forskjellig. En ACE-modell innebærer at normalavkastningen på kapitalen ikke skattlegges på selskapenes hånd og skal dermed $\mathrm{i}$ teorien sikre at selskapsskatten ikke øker avkastningskravet på investeringer i Norge. Med dagens norske regler skjermes normalavkastningen på den personlige eierens hånd. Ved å flytte skjermingen fra aksjonærene til selskapene, vil også normalavkastningen på utlendingers investeringer i Norge skjermes. Dette kan øke insentivene til å investere i Norge. En full utbytteskatt på norske aksjonærer (uten skjerming) kan imidlertid føre til at overskudd i større grad blir holdt tilbake i selskapene. Skattereglene kan dermed bidra til innlåsing av kapital i det enkelte selskap, slik at kapitalen ikke blir kanalisert dit den kaster mest av seg. En CBIT-modell vil på sin side øke avkastningskravet på gjeldsfinansierte investeringer og dermed isolert sett svekke insentivene til å investere i Norge. En CBIT-modell vil imidlertid, i motsetning til en ACE-modell, gi økte skatteinntekter som kan gi rom for redusert selskapsskattesats. Samlet vil en CBIT-modell kombinert med redusert selskapsskattesats innebære at man skifter skattebyrden fra renprofitt over på marginale prosjekter. Dette kan bidra til at færre investeringer framstår som lønnsomme, men samtidig at insentivene til å lokalisere investeringer som gir mobile renprofitter i Norge øker. CBIT-modellen vil fjerne insentivene til overskuddsflytting gjennom tynn kapitalisering, ved å nekte fradrag for gjeldsrenter. Dersom selskapsskattesatsen reduseres, vil det også kunne redusere insentivene til andre former for overskuddsflytting, jf. avsnitt 2.3. Ingen land 
har så langt innført en CBIT-modell. Dette kan blant annet skyldes at modellen reiser betydelige utfordringer i beskatningen av finanssektoren og i integrasjon med personbeskatningen.

Det norske skatteutvalget er bedt om å vurdere begge disse modellene, jf. avsnitt 2.4 .

\subsection{Overskuddsflytting og uthuling av skattegrunnlaget (BEPS)}

Forskjeller i selskapsbeskatningen mellom land skaper tilpasningsmuligheter for flernasjonale konsern som kan tilpasse prisingen av interne transaksjoner og utnytte forskjeller i lands interne lovgivning og svakheter i skatteavtalenettverk for å flytte skattbart overskudd fra høyskatteland til lavskatteland. Slike tilpasningsmuligheter kan over tid gi betydelige utfordringer med å opprettholde inntektene fra selskapsskatten i Norge. Dette svekker også skattesystemets legitimitet og gir en uheldig konkurransevridning ved å favorisere selskaper som har mulighet til å foreta slike tilpasninger.

Skattlegging av flernasjonale konsern krever at overskuddet kan deles mellom datterselskapene i ulike land. Konvensjonen internasjonalt er at selskapsoverskudd skattlegges i det landet overskuddet opptjenes (kildelandet). I flernasjonale konsern hvor produksjonen foregår på tvers av landegrenser, vil fordelingen av overskudd mellom land avhenge av hvordan innsatsfaktorene avlønnes. Armlengdeprinsippet er det grunnleggende prinsippet for fordeling av skattegrunnlag mellom parter i interessefellesskap, både i norsk skattelovgivning og i skatteavtaler. Armlengdeprinsippet fastslår at interne transaksjoner skal gjennomføres på samme vilkår, herunder til samme pris, som sammenlignbare transaksjoner mellom uavhengige parter. I mange tilfeller kan det imidlertid være vanskelig å finne et relevant sammenligningsgrunnlag. Dette gjelder særlig transaksjoner som involverer immatrielle eiendeler. Flernasjonale konsern vil også ha insentiver til å finansiere konsernselskaper i høyskatteland med gjeld (tynn kapitalisering), herunder lån fra konsernselskaper i lavskatteland. Slike tilpasninger kan forsterkes ved at det tas en høy rente på det interne lånet. Erfaringsmessig kan det være svært krevende å bruke armlengdeprinsippet på grenseoverskridende forhold.

Insentivet til slik overskuddsflytting avhenger på marginen av de formelle skattesatsene. Redusert selskapsskattesats vil likevel bare i begrenset grad kunne løse problemene med overskuddsflytting, så lenge enkeltland opererer med svært lav eller ingen beskatning. Målrettede tiltak mot overskuddsflytting anses derfor som nødvendig for å begrense problemet.

Norge innførte fra 1.1.2014 begrensninger i rentefradraget for selskaper, jf. avsnitt 1.3. Finansdepartementet har anslått at begrens- 
ningen vil øke provenyet fra selskapsskatten med om lag 2,5 mrd. kroner.

Norges handlingsrom for å innføre regler mot overskuddsflytting og uthuling av skattegrunnlaget er begrenset som følge av internasjonale forpliktelser, først og fremst gjennom EØS-avtalen. I tillegg vil det ligge reelle begrensninger i beskatningsretten gjennom skatteavtalene. På flere av områdene vil det dessuten være nødvendig med koordinerte løsninger mellom land forankret $\mathrm{i}$ internasjonalt samarbeid. Det pågår et bredt internasjonalt arbeid mot aggressiv skatteplanlegging, blant annet gjennom BEPS-arbeidet i OECD der Norge deltar aktivt og ulike initiativ i EU.

\subsubsection{Omfanget av overskuddsflytting i Norge}

Ettersom mulighetene for overskuddsflytting blant annet skyldes skjev informasjon, ligger det i sakens natur at det er vanskelig å gi et presist anslag på omfanget. En rekke internasjonale studier har likevel forsøkt å undersøke omfanget av overskuddsflytting, enten direkte ved å se på ulikheter i gjeldsgrader eller priser mellom land, eller indirekte ved å se på ulikheter i rapportert overskudd.

I Norge har forskere ved Senter for næringslivsforskning (SNF) gjort flere studier som sammenligner profitabiliteten til flernasjonale og nasjonale selskaper. Tanken er at flernasjonale konsern har muligheter til skattemotivert overskuddsflytting. Flytting av overskudd til andre land forventes å slå ut i lavere profitabilitet (overskudd som andel av inntekt) i de norske selskapene.

Langli og Saudagaran (2004) ${ }^{10}$ studerer forskjellene i profitabiliteten til norskeide og utenlandskeide selskaper i industri-, engros- og detaljhandelssektoren fra 1993 til 1996 og kommer fram til at utenlandskeide foretak har 2,6 prosentpoeng lavere profittmargin enn de norskeide foretakene.

Tropina m.fl. (2010) ${ }^{11}$ utvider tidsperioden til 2005 og finner resultater som peker i samme retning. Resultatene indikerer at flernasjonale selskaper (inkludert norskeide selskaper med utenlandske datterselskaper) i Norge rapporterer lavere lønnsomhet enn de rent nasjonale selskapene. Foretak som er del av norske eller utenlandske flernasjonale selskap har også 10 til 15 prosentpoeng høyere sannsynlig-

10 Langli, J.C. og M.S. Saudagaran (2004): “Taxable Income Differences Between Foreign and Domestic Controlled Corporations in Norway", European Accounting Review, Vol. 13, No. 4, 713-741, 2004.

11 Tropina, J. (2010): “Tax income differences between multinational and domestic corporations in Norway: A panel data approach", SNF project no 1185 "Profit-shifting in Norway: A Theoretical and Empirical Analysis". 
het for ikke å være i skatteposisjon enn rent norske foretak i samme bransje og med sammenlignbar størrelse og gjeldsgrad. Tropina viser også at lønnsomheten går ned med om lag 20 pst. når et nasjonalt selskap blir flernasjonalt. Møller og Nordal (2012) ${ }^{12}$ utvider tidsperioden til 2007 og finner tilsvarende resultater. Funnet av differanse i lønnsomhet ser derfor ut til å være robust over tid.

Studiene fra SNF indikerer at om lag 30 pst. av det potensielle skatteprovenyet fra utenlandske flernasjonale foretak går tapt. Ifølge Tropina (2009) stammer om lag 10-15 pst. av selskapsskattegrunnlaget fra utenlanskeide selskap.

Internasjonale studier har også studert sammenhengen mellom internasjonale handelspriser til hhv. eksterne og tilknyttede selskap og skattesatser i landene det handles med.13 Lignende studier kan ikke gjennomføres i Norge, da norske tolldata ikke inneholder informasjon om hvorvidt handelen skjer med et beslektet selskap.

\subsection{Skatteutvalgets mandat}

I mars 2013 ble det oppnevnt et selskapsskatteutvalg som skal vurdere om beskatningen av selskaper i Norge er godt nok tilpasset den internasjonale utviklingen. Utvalget skal blant annet vurdere:

- $\quad$ om selskapskapsskattesatsen bør reduseres.

- mulighetene for flytting av inntekter og fradrag mellom land med sikte på å spare skatt og utrede tiltak som kan beskytte det norske skattegrunnlaget.

- $\quad$ om forskjellen i skattemessig behandling av gjeld og egenkapital fra utenlandske eiere skaper rom for tilpasninger, og om et tiltak for å beskytte det norske skattegrunnlaget kan være å likebehandle gjeld og egenkapital (CBIT eller ACE).

- $\quad$ om fritaksmetoden gir uheldige tilpasningsmuligheter ved grenseoverskridende aksjeinntekter.

- $\quad$ om en bør skyve noe av skattebyrden fra selskapsskatten over på mindre vridende skatter.

Utvalget skal også gjennomgå og komme med forslag til å forbedre systemet for skattemessige avskrivninger. Utvalget skal levere sin innstilling innen 2. december 2014.

Det er i utvalgets mandat pekt på at en eventuell reduksjon i selskapsskattesatsen må vurderes i sammenheng med det øvrige skattesystemet, herunder forholdet mellom person- og selskapsbeskatnin-

12 Møller, R. og E.A. Nordal (2012): “FoU og overskuddsflytting i Norge", SNF Arbeidsnotat 36/12.

13 Jf. bl.a. Clausing (2003) og Bernard, Jensen og Schott (2006). 
gen. De ulike delene av det norske skattesystemet er tett integrert, med en felles sats på alminnelig inntekt for personer og selskaper. Beskatningen av eierinntekt er basert på et felles prinsipp uavhengig av om inntekten stammer fra enkeltpersonforetak, deltakerlignet selskap eller aksjeselskap. Videre er systemet basert på en harmonisering av de høyeste marginalskattesatsene på arbeidsinntekt og aksjeinntekt for å unngå inntektsskifting. Dette antas å ha redusert tilpasningsmuligheter og bidratt til stabilitet og forutsigbarhet, men gir samtidig utfordringer når en skal vurdere endringer i deler av skattesystemet. 